\title{
Management of penetrating abdominal trauma in St Mary's Hospital Major Trauma Centre
}

\author{
Rachael C Fisher*, Carina McGuire, Christopher J Aylwin \\ From London Trauma Conference 2014 \\ London, UK. 9-12 December 2014
}

\section{Background}

There continues to be a debate into the management of penetrating abdominal injury. The use of $\mathrm{CT}$ has improved the safety of conservative management and laparoscopy in trauma has been postulated as an alternative to trauma laparotomy [1].

\section{Method}

A retrospective review was undertaken of all patients admitted as a trauma call to St Mary's Hospital between January $1^{\text {st }} 2012$ to $30^{\text {th }}$ April 2014 with penetrating abdominal trauma. Information was obtained regarding their mechanism of injury and management through the $A+E$ symphony database, PACS system and the discharge letter database.

\section{Results}

145 patients were identified, 135 males and 10 females, average age 29. Stabbing was the mechanism of injury most frequently accounting for $77 \%(111 / 145)$ of presentations. In total $36 \%$ of injuries were managed conservatively, with $64 \%$ undergoing operative management.

The median length of stay for isolated abdominal injuries, irrespective of pathology found, ranged from 1 day in those conservatively managed; 1.5 days in those undergoing laparoscopy; to 6 days for those undergoing a laparotomy.

In patients who had negative intraabdominal pathology the median length of stay was 1 day for both conservatively managed and laparoscoped patients compared to 2 days if they underwent an exploratory laparotomy. Notably $50 \%$ of all laparoscoped patients had negative operative findings.

* Correspondence: r.fisher@doctors.org.uk

Major Trauma Ward, St Mary's Hospital, London, UK

\section{Discussion}

Our data shows laparoscopy as a safe alternative to laparotomy in penetrating abdominal trauma, halving the median length of stay. Although laparosocopy has a lower risk profile, $50 \%$ of laproscoped patients had negative findings, potentially suitable for conservative management.

Laparosocopy may be an option for equivocal findings, however the combination of advancing imaging techniques and accuracy of reporting suggest operative management could be reserved for haemodynamically unstable and radiologically proven injuries.

\section{Published: 11 September 2015}

Reference

1. Heselson J: An expanded definition of the adult respiratory distress syndrome. Cent Afr J Med 1963, 9:395-398.

doi:10.1186/1757-7241-23-S2-A9

Cite this article as: Fisher et al:: Management of penetrating abdominal trauma in St Mary's Hospital Major Trauma Centre. Scandinavian Journal of Trauma, Resuscitation and Emergency Medicine 2015 23(Suppl 2):A9.

Submit your next manuscript to BioMed Central and take full advantage of:

- Convenient online submission

- Thorough peer review

- No space constraints or color figure charges

- Immediate publication on acceptance

- Inclusion in PubMed, CAS, Scopus and Google Scholar

- Research which is freely available for redistribution 